\title{
A CRITICAL OVERVIEW ON DEVELOPMENT- WELFARE, POWER OR DOMINATION
}

\author{
Chaudhary, Deepak ${ }^{5}$
}

\begin{abstract}
Development is quite a mixture approach as well as a continuous process. It serves as a mirror of changing economic and social capacities, and choices to make development more democratic and sustainable. The post-development paradigm sees all modern concept of development has been failed. Nepal cannot be exceptional from it, as it is struggling towards modernization and development, although some human development indexes seem to be improved. However, the discourse on development has frequently been questioned in Nepal due to its slow pace. Meanwhile, East Asia or China, Asia-Pacific countries changed such assumptions making huge economic progress. Therefore, it will be wrong to blame that the development has completely been failed. It is true that the globalization and advancement in technology have also created complexities worldwide and traditional approach of development may not work effectively because many new social, economic and environmental issues and problems have been raised over decades. The proper approach must consider the existing global context for sustainability and humanity, but not only domination of elites. Presently, good governance and people-centric issues have become a crucial part for the development. To make development more acceptance and sustainable, genuine and rational issues which are relating to human and environment must be considered. This paper aims to analyze the development approaches based on historical approach analyzing the past developments and reviewing development theories and make some suggestions for its suitability.
\end{abstract}

Keywords- Globalization, good governance, post-development, people-centric, sustainability

\section{Background: Development discourse}

The word 'Development' can be heard everywhere in daily life. Simply, people consider development means a change or something happens differently. The development is as a process or course of change dynamic. At the beginning of the 18th century, development was considered as a remedy for progress; progress was on the center of development in Europe at that time 5 Mr. Chaudhary is a PhD Scholar of Rural Development, Tribhuwan University can be contacted at dipak10@gmail.com 
because the society's nature was a tradition and feudal in many respects. For Hegel, progress is linear and development curvilinear (from Pieterse, 2010). Following the industrialization in the mid-18th century, the modern development process was considered to have begun. The modern concept of development came from the industrial development of Europe/America. The colonial legacy was important in making the formation of development; the colonization did spread the concept of European development worldwide. Resource management was the sole part of the colonial economy. On the other hand, the dark part of the colonial economy was as what Pieterse (2010) argues that it destroyed native manufactures i.e. textile in India. Colonies emphasized on industrialization absorbing recourses from south global part but it left people uprooted (Jason, 2017). The economic crisis in Europe in 1930 led the state welfare in economic development additionally. All development thinkers from Adam Smith, Ricardo, and Marx to Keynesian emphasized economic development for human prosperous suggesting different ways.

Following World War II, many countries came into the surface as a nation-state and development were introduced in planning and systematic way through institutions to set up the new politicaleconomic structure. The social and economic department of the United Nations (UN) initiated development programs with western investment and technology. However, the world was divided into two groups such as capitalism and communism blocks between 1945 and 1990 . During the Cold-War years of rivalry between capitalism and communism; the two competing development strategies were 'western development economics' led by United States (US) and 'central planning' development approaches led by Union of Soviet Socialist Republic (USSR). Following the success of the master plan in Western Europe implemented by the US, the concept of modernization was introduced in order to develop to third countries and third countries were considered as underdeveloped. Both capitalism and communism blocks targeted third countries in order to change traditional societies in modern ways and economic growth was as the central part of the development. Former American president Henry Truman announced the development program in 1949 through the aids and technology for third countries in order to make developed; it is also known as modernization theory. It was assumed that third countries were underdeveloped. The main purpose of Truman's plan was to bock the influence of communism.

"More than half the people of the world are living in conditions approaching misery. Their food is inadequate; they are victims of the disease. Their economic life is primitive and stagnant. Their poverty is a handicap and a threat both to them and to areas that are more prosperous. For the first time in history humanity possesses the knowledge and the skill to relieve the suffering of these people. . . . I believe that we should make available to 
Research Nepal Journal of Development Studies (Year $2^{\text {nd }}$ Issue $1^{\text {st }}, 2019$ May)

peace-loving peoples the benefits of our store of technical knowledge in order

to help them realize their aspirations for a better life." (Truman [1949] 1964)

On the other hand, the socialism approach led by USSR adopted fifth year planning based development that was controlled by the state and other socialist countries copied it. In this way, the concept of the third world/country emerged in the context of development. The World Bank in 1949 put the first mission of formulating a comprehensive development strategy for Columbia; it included 14 international advisors in development fields. Similarly, the United Nations Department of Social and Economic Affairs (1951) wrote in 15 Article for Economic Development of Underdeveloped Countries, as follows:

"There is a sense in which rapid economic progress is impossible without painful adjustments. Ancient philosophies have to be scrapped; old social institutions have to disintegrate; bonds of caste, creed, and race have to burst; and large numbers of persons who cannot keep up with progress have to have their expectations of a comfortable life frustrated. Very few communities are willing to pay the full price of economic progress." (from Escobar, 1995)

According to Escobar (1995), two things emerged during the development discourseprofessionalization and institutionalization. The nature of development implemented by World Bank was to intervene in social and economic aspects, careful planning, organization and allocation of resources. After 1960, modernization concept of the development was criticized because resistance emerged in many parts of the world, as it could not go below and debt-problem emerged as a worldwide problem. As a result, the new approaches to development discourse emerged after 1970; indigenous, climate, human development and so on issues emerged that had to be considered into account.

The 'Washington Consensus' in 1989 came as development strategies focusing around privatization, and liberalization; it emphasized on Laissez-faire concept of market and minimizing the role of government. After 1990, the human development approach has been implemented worldwide; it emphasized education and health along with the growth. However, many countries failed to achieve the development goals due to various reasons. Many challenges regarding the development were surfaced. Later on, climate change and environment issues were included in the development perspective and community based and sustainable development approaches emerged. All these approaches emerged as a part of post-development and these all emphasized people, their choice, and capability as well as freedom. 


\section{Purpose of the study and Methods}

This paper provides an overview regarding the development trends and approaches worldwide and Nepal as well. This work is based on analysis and literature review. The study is exploratory and analytical in nature because it intends to explore the focus of the trends of development worldwide as well as Nepal. The study uses secondary data for the fulfillment of the study. The theories regarding the development are also extensively reviewed. Some development experts were interviewed as key informants.

The development can be understood as different ways over time as follows:

\section{Discussions}

\section{Growth versus Development}

In the period between 1940 and 1970, the core meaning of development was economic growth and it was more popular for economic development. The theorists of 1950 \& 1960 viewed the process of development must pass through economic growth. The accumulation of assets (capital, labor, and land) and making production were the key assumptions for rapid economic growth. Harrod-Domar Growth Model, Solow Growth Model, Keynesian Growth Model, and Rostow's Stage Growth models were famous as economic growth models. After 1970, it has realized that development is more than growth because it could not eradicate poverty as what the world expected. Generally, economic growth refers to an increase over time in a country`s Gross National Production (GNP) or real output per capita income whereas economic development implies for income, savings and investment along with progressive changes in the socioeconomic structure of the country (Todaro, 2012).

\section{Development as a power-knowledge relation:}

Development cannot free from power relation approach. Edward Said (1970) writes- development is a systematic discipline by which European culture was able to manage and even produce the Orient politically, sociologically, militarily, ideologically, scientifically and imaginatively during the post-enlightenment period. Foucault Michael (1978) mentions that power and knowledge are intimately connected and directly imply one-another. According to him, the development is historically produced-phenomena through the interaction of power-knowledge exercise. The exercise of power-knowledge for a long creates subjectivism and it creates 'truth' in acceptance form. He argues that thinking about development in terms of discourse enables us to maintain a focus on power and domination. Thus, continuous attempts of power-knowledge exercise create 
development. The creation of knowledge regarding the development is important and it is related to power, domination or hegemony too. The discourse of production and circulation is an integral component of the exercise of power. The politics of truth is created and maintained and, ultimately, it produced knowledge for the development.

\section{Development Approaches:}

The development approaches can be understood in three categories -

Main Stream approach

Radical approach

Post-development approach

\section{Main Stream/Top to Bottom Approach}

It is also called the Trickle down approach. In this approach, the central government implements the policy in order to bring investors. Big investors/larger companies are the driving force behind economic growth is the main assumption of the trickle-down approach. The concepts of supply and demand, off-free trade, and of few government restrictions are the major features of this approach. As per the approach, the government should have a very limited role in the economy. Following the economic crisis in 1930, Keynesian emphasizes government spending on the public sector and infrastructure to boost the economy and provide jobs. The mainstream approach views poverty because of being 'left out' of processes of development. However, many third countries' experience has been bitter in the sense that this development approach could not reach below. However, some countries like East Asians have made success story adopting this polices. In this approach, the state's direct and frequent intervention is not supposed to be good. It is also called a liberal approach. Revolution or radical policies are avoided in this approach. Many countries have improved this approach adding social welfare, safety nets, and human sustainable development.

\section{Radical/Central Planning Approach}

State intervention is a major feature of this approach. It vehemently criticized Mainstream approach saying that revolution is the basis for this approach. It is believed that production and distribution should be balanced and poor people must be benefitted. The radical approach supports having significant government control over the functioning of the economy. The government is actively involved in making economic plans and decisions. Marxist revolution and state control's 
approach are examples of this approach. This approach was seen in many of the Eastern European countries after World War II. After the downfall of USSR in 1989, this approach has frequently been questioned. Even communist countries like China and Vietnam have been adopting the freemarket economic system and made economic progress.

\section{Post-Development Approach}

The last 40 years (from the end of World War II to 1990) is called the age of development. Alternative approaches are being discussed due to the failure of past development in many underdeveloped countries. It created a huge amount of inequality worldwide and resistances emerged. The past developments are being criticized saying that outsiders enforced the development in the past where bottom-level people were neglected. Rich became rich, and the poor became poor and inequality increased lavishly. The World Bank's 'The Changing Wealth of Nations 2018 report' reveals that getting rich is not about liquidating natural capital to build other assets-natural capital per person in high-income Organization for Economic Co-operation and Development (OECD) countries was three times that in low-income countries in 2014.

The degradation of the environment hit the poor and depth of poverty increased; the indigenous people probably paid a huge amount in the name of development. Many countries suffered from debt and loan and became dependent on what dependency theory argues. On the one hand, ecological and biodiversity have emerged as a key factor that has to be considered and on the other hand the concept of 'equality' is emerging that needs to be addressed. In these circumstances, alternative approaches have pronounced. Escobar (1995) argues seven decades after World War II, certain fundamentals have not changed; global inequality remains severe, both between and within nations. Globalization was another factor that contributed to the new approach to development. Exclusion of poor people, inequality, climate change, and debt-crisis and so on are considered to have the major reasons behind the emergence of post-development.

Already, during the 1980 s, some scholars and activists were articulating dissatisfaction with the concept and practice of 'development' that was explicitly not calling for a better, alternative version of it (Ziai, 2007). Ziai further mentions that industrial model of society could no longer be conceived as ahead in the evolutionary scale in the light of the ecological predicament, but a 'misconceived enterprise' in that it implicitly aimed at eliminating cultural diversity through the universalizing of Western institutions.

Post-development theory blames that the whole concept and practice of development in the past was a reflection of Western-Northern hegemony over the rest of the world. Post-development 
Research Nepal Journal of Development Studies (Year $2^{\text {nd }}$ Issue $1^{\text {st }}, 2019$ May)

thinkers believe that the failure of development and the new arising-problems have led to a loss of faith in development. They believe that mainstream development diminished people participation, underestimated local capacity and center enforced a development on a local level. Broadly, more alternatives are proposed like sustainable development, social development, Human Development, Right based approach, capability/freedom, and so on.

\section{Basic Need-based Approach:}

The 'basic needs' approach was introduced by the International Labour Organization's (ILO) World Employment Conference in 1976 which proposed the satisfaction of basic human needs as the overriding objective of national and international development policy. The food (including water), shelter and clothing are considered as the 'basic needs'. Recently sanitation, education, and healthcare are also added in basic needs. Basic needs are related to psychological health and well-being. To eradicate poverty, these basic things are considered to be essential.

"The need to focus on the poorest groups in the rural population was stressed. The fields to which special attention should be paid by the ILO were identified as being training, rural women, organizations of rural workers, co-operatives, the organization of labor-intensive works, and the collection and analysis of information as a basis for rational policymaking and programming in rural development...... We must fulfill our responsibility under the terms of the Declaration of Philadelphia, to examine " all national and international policies and measures, in particular, those of an economic and financial character "in the light of the contribution they can make to the promotion of freedom and dignity, economic security and equal opportunity." (ILO, 1968)

\section{Endogenous Development Approach}

The idea of endogenous development has emerged in the form of alternative development as it indicates about culture in respect of its development. It is assumed that each culture has its own indigenous knowledge and the development approach can be pursued. When goals and values are generated from within the culture, it also generates self-confidence. In past traditional value and culture were considered to have been an obstacle for the development. Simply, endogenous means 'growing from within'; endogenous development is based on people's own resources, strategies, and initiatives.

\section{Participatory Development Approach /the People-Centered Approach}

In order to avoid local conflicts, local people are given high priority in project planning and development. In rural areas, local people themselves are considered the main implementers of 
development projects. A project that the local people themselves plan and implement is given priority as local materials and human resources are utilized effectively. Participating people in the project make the project sustainable and society friendly which avoids the social conflict. The Framework for mainstreaming participatory development processes in Asian Development Bank (ADB) was introduced in 1996 in response to the need for ADB to do more to enhance the sense of ownership among beneficiaries.

Bhatnagar, Bhuvan, and Aubrey C. Williams (1992), in their Participatory Development and the World Bank: Potential Directions for Change, World Bank Discussion Paper 183 report mention participatory development as follows:

"Participatory development is an end and a means. It is an end because participation builds skills and enhances people's capacity for action and for enriching their lives. It is a means because participations contribute to better development policies and projects. As a development agency, the World Bank is primarily concerned with exploring individuals, communities and public and institutions can contribute to making development prospects better and more lasting." (P. 183)

\section{Right Based Approach}

The equal and inalienable rights of all human beings provide the foundation for freedom, justice, and peace in the world, according to the Universal Declaration of Human Rights, adopted by the UN General Assembly in 1948. Prioritizing the application of human rights principles became a cornerstone of UN reform efforts initiated in 1997. UNFPA was one of the agencies that in 2003 adopted the UN Common Understanding on a Human-Rights-Based Approach (HRBA) to development cooperation, which clarifies how human rights standards and principles should be put into practice in programming. The human rights-based approach focuses on those who are marginalized, excluded or discriminated. UNFPA and its partners now work to fulfill the rights of people, rather than the needs of beneficiaries. Right-based approaches can be understood its nature such as poor, women, Dalits, and the ethnic minorities must get equal opportunity and an environment to participate in politics for people can make an environment to get an education, health services, and social security in remote areas.

\section{Sustainability Livelihood Approach}


Research Nepal Journal of Development Studies (Year $2^{\text {nd }}$ Issue $1^{\text {st }}, 2019$ May)

The idea of 'sustainable development' became widespread with the 1987 publication of 'Our Common Future', a report from the World Commission on Environment and Development (the Brundtland Commission; UN 1987); Its definition of "development which meets the needs of the present without compromising the ability of future generations to meet their own needs". The key principle of sustainable development focuses on the integration of environmental, social, and economic concerns into all aspects of decision-making. The overall goal of sustainable development (SD) is the long-term stability of the economy and environment; this is only achievable through the integration and acknowledgment of economic, environmental, and social concerns throughout the decision-making process.

Most people living in fragile environments are poor, and poor people more frequently rely on the environment for their livelihood. The adverse impact of global climate change in livelihoods is inevitable and same as the accumulation of greenhouse gases. To cope with these impacts and make the livelihood and development long-lasting, sustainable development is essential. Sustainability is the foundation for today's leading global framework for international cooperation - the 2030 Agenda for Sustainable Development and it is Sustainable Development Goals (SDGs). Each of the 17 SDGs has specific targets to be achieved by 2030 . These 17 SDGs are as follows: -

"No Poverty, Zero Hunger, Good Health and well-being, Quality education, Gender Equality, Clean water and sanitation, Affordable and clean energy, Decent work and economic Growth, Industry, innovation and infrastructure, Reduced Inequalities, Sustainable cities and communities, Responsible production and consumption, Climate change Action, Life below water, Life on land, Justice and strong institutions and Partnership for the goals."

(source: https://www.un.org/sustainabledevelopment/sustainable-development-goals/)

\section{Human Development Approach}

In the 1970s and 80s development debate considered using alternative focuses to go beyond GDP and human development approach surfaced. Human Development concept was first introduced in 1990 by UNDP preparing Human Development Report where human beings are put in the center of development policy. According to Human Development Report 1990, 'Human development is a process of enlarging people's choices; the most critical of these wide-ranging choices are to live a long and healthy life, to be educated and to have access to resources needed for a decent standard of living'. Sen (2000) argues that the expansion of freedom is central to development. 
Chaudhary. Deepak

In the wake of human capital formation, the role of human development is vital. The Human Development is measured by Human Development Index (HDI) is a statistic (composite index) of life expectancy, education, and per capita income indicators, which are used to rank countries into four tiers of human development. A country scores higher HDI when the lifespan is higher, the education level is higher, and the GDP per capita is higher.

\section{Non-Governmental Organizations (NGOs)}

Generally, NGOs are supposed to be a non-profit organization and it has become third sector actor on the landscapes of development, human rights, environment, and many other areas of public action. Article 71 of the UN Charter forms the basis for granting non-governmental organizations Consultative Status as follows - "The Economic and Social Council may make suitable arrangements for consultation with non-governmental organizations which are concerned with matters within its competence. Such arrangements may be made with international organizations and, where appropriate, with national organizations after consultation with the Member of the United Nations concerned." Legal UN Repertory claims.

The international donors are used the NGOs to bridge the project/donor and people. NGOs are used to make awareness and to implement corporate social responsibility. NGOs role in alleviating poverty in rural areas assumes to be vital. It makes people aware of their right. Sometimes it challenges the government's role in development; therefore, some authoritarian based countries have been strictly watching NGOs' activities.

\section{Nepal: Development and Underdevelopment}

Mishra (1987) argues that the onset of underdevelopment in Nepal ensued from the mid of 1880 AD. Nepal had intimacy with British-India and she led capitalism in the world at that time. Competitive Capitalism was at a peak and the British were considered as a super Power/ center. Remittance was the main economic source for Nepal; a huge number of Nepali youth was recruited in the British army. Labour had become the prime source of income of the country and that is why it is called modern capitalism was introduced in Nepal since 1885 . Between $1891 \&$ 1931, there was a fivefold increase in the number of Nepali migration to Sikkim, Darjeeling \& Assam and in returns; the huge capital was flown inside the country. Trade was increased from 9.8 million in $1879-80$ to 87.9 million in $1920-21$. After the British-India \& Nepal war, Nepal had good opportunities for consolidation and development; but there is no evidence that these opportunities were properly utilized or even realized, the sole objective of official policy of Ranas was maintenance of the status quo while averting dangers to national independence and security 
Research Nepal Journal of Development Studies (Year $2^{\text {nd }}$ Issue $1^{\text {st }}, 2019$ May)

of the regime (Regmi, 1999). Actually, a huge amount received from British-India for recruiting Gorkha army, however, Ranas was reluctant to develop the country instead they utilized the public assets in their private life. After 1950 revolution, Nepal adopted democratic norms and values and opened for international door and organizations for the development. Planned base development was implemented after the 1950's change and private investment was also encouraged. From 1956, fifth-year plan based development started for national self-sufficient.

The World Bank Group (WBG) fielded its first economic mission to Nepal in 1963 to assess the country's development prospects and challenges (Hagen, 2012). It approved its first credit in 1969 for a telecommunications project. Since then, the World Bank has provided Nepal billions as assistance. However, Nepal could not develop its export-oriented big industrialization concept and as a result imports as a percent of GDP went up from 9\% to 15\% between 1969 and 1970 and deficiency went on. Nepal also failed to attract Foreign Direct Investment (FDI) as still only accounts for 0.6 percent of GDP (https://www.worldbank.org/en/country/nepal/overview\#2). However, Nepal remained at the bottom of the ranking in attracting FDI. The World Investment Report 2011 places Nepal at 134th position in the inward FDI performance Index. Furthermore, Nepal could not afford large-scale capitalist accumulation.

According to Mishra, the faults of policy made difficult for production and export. For instances, land reforms were not effective and landlessness \& rural people could not get benefits. Unsuccessful in the new Education System Plan was another example that could not comprehend the relationship between class and production. The development has very little to do despite an abundance of resources. According to Pyakuryal (2013), since the Rana regime during 18461950 through 2013, Nepal has experienced continuous swings in its economy in its economic performance; the experiments have largely been unsatisfactory in reducing income inequality. Due to the underdevelopment and unemployment, resistances were surfaced. As a result, the polity was changed in 1990; the country adopted a liberal democracy. After 1990, liberalization, globalization, and privatization based economic policies were implemented but it could not succeed due to intra-party conflict and Maoist insurgency from 1996 to 2006. One positive aspect of 1990-change that it increased awareness in the people of their rights and self-esteem. Likewise, alternative development approaches like participatory, human development and sustainable approaches were also given priority. The globalization was expected to reduce inflation but it was not wholly true. Pyakurel pessimistically analyzes the Nepali economic.

Pandey (1999) mentions that the word 'bikas' sells in the country -as a dream, as an occupation; and as a weapon to beat one's political opponents with, but the subject has not been internalized 
as a mission. Bista (1991) points out that Nepal has been struggling towards modernization (development). Recently, poor-infrastructural developments, poverty and inequality are major challenges in Nepal.

\section{Conclusion}

The development approaches have long been concentrated in reducing poverty, inequality, and welfare in society for decades. Nevertheless, it's linkage with power and domination is also not hidden. Global-north had been dominated the world for centuries because of development in political, technology, military and economy. However, World order has slightly been shifting from north to southeast in recent days due to the expansion of development after globalization. For instance, China is competing with the US and it is believed that she will surpass world number one economy- US, in the near future because of tremendous development in social, economic, military and technological fields. Therefore, development seems to be major factor that shaping world order. Sahle (2010) examines how hegemonic development ideas and practices emerged in the context of the changing world order post-1945 and how this transformation was characterized by neoliberalism and securitization of development and security.

Even, left political wings embraced neoliberalism and took huge benefits from it. It is not concealed that Communist China and East Asia largely benefited from neoliberalism and globalization and China has now become the pioneer of globalization. One thing is clear that if there are effective leadership and governance, globalization and development can be tackled. Presently, good governance has become a buzzword in political economy that emphasizes the rule of law rather than ideologies. It is an essential tool or system for achieving development. The grasping of the development depends upon the country's political economy, governance, and leadership. Ziai (2016) analyzes the orientation towards development - one that is skeptical of contemporary neoliberal approaches to economics, while also not embracing traditional left-wing responses to neoliberalism.

Nevertheless, protectionism in politics is also being emerged globally after 2015 that is making harm neo-liberalism to the extent. The neo-liberalism seems to have been succeeded in the expansion of technology and assets in a rapid way worldwide despite the crony-capitalism. The reforms may be needed in regard so that inequality could be reduced. The policy should be concentrated on poor and marginalized people's grievances instead of focusing on elite. On the other hand, the post-development approach is also not free from critics. It has been blamed for being utopian; the post-development itself could not provide proper and concrete vision and solution. Likewise, globalization and advancement in technology have also created complexities and problems so 
Research Nepal Journal of Development Studies (Year $2^{\text {nd }}$ Issue $1^{\text {st }}, 2019$ May)

far. However, it does not mean that post-development should completely be ignored; its major issues like participation, culture, human right, and sustainability have become a part of human life. The precise approach of development must concentrate on human welfare and freedom so that everyone (also inclusive) may be able to choose their desires. Access to basic education and health for all must be ensured. The development based on sustainability, inclusiveness and human development may be more relevant at this time because it covers humans and its dimensions as well as the environment. After that only the concept of development will be meaningful for a large population particularly rural and poor population and development may be flourished for a welfare society rather than domination.

\section{References:}

Aram, Z. (2007). Exploring Post-development: Theory and practice, problems and perspective. (Z. Aram, Ed.) London: Routledge.

Bhatnagar, B. and Aubrey, C. W. (1992). Participatory Development and the World Bank: Potential Directions for Change; Discussion Paper 183. Washinton DC: World Bank.

Bista, D. B. (1991). Fatalism and Development. Hyderabad: Orient Longman Private Limited.

Escobar, A. (1995). Encountering Development: The Making and Unmaking of the Third World. New Jersey: Princeton University Press.

Geiser, U. (2014). Contested Development in Nepal: Experiences and Reflections. (U. Geiser, Ed.) Kathmandu: Kathmandu University \& Nepal Centre for Contemporary Research (NCCR).

Hagen, T. (2012). Decentralization and Development. Kathmandu: HimalAsia Foundation. http://legal.un.org/repertory/art71.shtml. (n.d.).

https://www.un.org/sustainabledevelopment/sustainable-development-goals. (n.d.). https://www.worldbank.org/en/country/nepal/overview\#2. (n.d.).

ILO. (1968). ILO AND Human Rights Report (Part 1). Geneva: International Labor Office. Jason, H. (2017). The Divide. London: Penguin Random House.

Michel, F. (1978). The History of Sexuality (Vol. 1). (R. Hurley, Trans.) New York: Pantheon Books. 
Nederveen, P. J. (2010). Development Theory (2 ed.). New Delhi: SAGE.

Panday, D. R. (2009). Nepal's Failed Development Reflections on the Misson and the Maladies (10 ed.). Kathmandu: Nepal South Aisa Center.

Pieterse, J. N. (2010). Development Theory (2 ed.). London: SAGE.

Pyakuryal, B. (2013). Nepal's Development Tragedy: Threats and Possibilities. Kathmandu: Fine Print.

Regmi, M. C. (1999). A Study in Nepali Economic History. New Delhi: Adroit Publishers.

Sahle, E. (2010). World Orders, Development Discourse and Coloniality. London: Palgrave Macmillan.

Said, E. W. (1978). Orientalism. US: Vintage Book.

Sen, A. (2000). Development as Freedom. New Delhi: Oxford University Press.

Sharma S. R, Upreti B. R., Manandhar P., \& Sapkota M. (2014). • Sharma Sagar Raj, Upreti Bishnu Raj, Manandhar Contested Development in Nepal: Experiences and Reflections. Kathmandu: Kathmandu University \& Nepal Centre for Contemporary Research (NCCR). source: https://www.un.org/sustainabledevelopment/sustainable-developmentgoals/. (n.d.).

Truman, H. S. (1949). Public Papers of the Presidents of the United States by Harry S. Truman. Washinton DC: Government Printing Office.

UN. (1987). Our Common Future. New York: Oxford University Press.

UNDP. (1990). Human Development Report 1990. New York: Oxford University Press.

UNDSEA. (1951). Economic Development of Underdeveloped Countries. New York: United Nations Department of Social and Economic Affairs.

WB. (2018). The Changing Wealth of Nations 2018: Building a Sustainable Future. Washinton DC: World Bank.

Ziai, A. (2016). Development Discourse and Global History: From Colonialism to the Sustainable Development Goals. London: Routledge. 